\title{
PROPRANOLOL PLASMA MONITORING IN CHILDREN SUBMITTED TO SURGERY OF TETRALOGY OF FALLOT BY A MICROMETHOD USING HIGH PERFORMANCE LIQUID CHROMATOGRAPHY
}

Cristina Sanches, Filomena R.B.G. Galas, Anne G.O. de M. Silva, Maria Jose C

Carmona, José Otavio Auler Jr., Silvia Regina Cavani Jorge Santos

Sanches C, Galas FRBG, Silva AGO de M, Carmona MJC, Auler Jr. JO, Santos SRCJ. Propranolol plasma monitoring in children submitted to surgery of tetralogy of Fallot by a micromethod using high performance liquid chromatography. Clinics. 2007;62(3):215-24.

OBJECTIVE: To evaluate the analytical micromethod using liquid chromatography for the quantification of propranolol in children submitted to surgery of tetralogy of Fallot (TLF). Methods: Only $0.2 \mathrm{~mL}$ of plasma is required for the assay. Peaks eluted at 8.4 (Propranolol) and $17.5 \mathrm{~min}$ (verapamil, internal standard) from a $\mathrm{C} 18$ column, with a mobile phase $0.1 \mathrm{M}$ acetate buffer, $\mathrm{pH}$ 5.0 , and acetonitrile $(60: 40, \mathrm{v} / \mathrm{v})$ at flow rate $0.7 \mathrm{~mL} / \mathrm{min}$, detected at $290 \mathrm{~nm}$ (excitation) and $358 \mathrm{~nm}$ (emission). Surgery was started $776 \mathrm{~min}$ of drug administration $(8.7 \mathrm{mg}$, mean); seven blood samples were collected from six patients (4M/2F; $2.1 \mathrm{yrs} ; 11.5 \mathrm{~kg}$; $\left.0.80 \mathrm{~m} ; 18.9 \mathrm{~kg} / \mathrm{m}^{2}\right)$.

RESULTS: Confidence limits of the method showed high selectivity and recovery, sensitivity of $0.02 \mathrm{ng} / \mathrm{mL}$, good linearity $(0.05-$ $1000 \mathrm{ng} / \mathrm{mL}$ ), precision of $8.6 \%$ and accuracy of $3.1 \%$. The mean duration of surgery was $283.2 \mathrm{~min}$, with the patients remaining under cardiopulmonary bypass (CPB) for 114min. A declining curve of propranolol plasma concentration was obtained after the last dose in the night that preceded the day of surgery. Plasma concentration also was normalized with hematocrit due to the hemodilution caused by the $\mathrm{CPB}$ procedure. On the other hand a decrease on drug plasma concentration was obtained between periods, the beginning of surgery to the postoperative day $2(7.09 \mathrm{ng} / \mathrm{mL}$ and $0.05 \mathrm{ng} / \mathrm{mL}, \mathrm{p}<0.05$ respectively) and from the end of CPB to the postoperative day $2(2.79 \mathrm{ng} / \mathrm{mL}$ e $0.05 \mathrm{ng} / \mathrm{mL}, \mathrm{p}<0.05)$.

CONCLUSION: Propranolol monitoring of plasma concentrations of children (TLF) normalized after the last preoperative dose revealed a decline from the beginning of surgery to the second postoperative day, suggesting that, once redistribution was restored, propranolol washout was complete.

KEYWORDS: Propranolol, Micromethod, Plasma concentration, Tetralogy of Fallot.

\section{INTRODUCTION}

Tetralogy of Fallot accounts for 10\% of all congenital heart diseases and is the most common cyanotic heart disease during infancy ${ }^{1}$. Few children are asymptomatic

School of Pharmaceutical Sciences - University of Sao Paulo Medical School, Sao Paulo/SP, Brazil.

Heart Institute, University of Sao Paulo Medical School, Sao Paulo/SP, Brazil. Email: pharther@usp.br

Received for publication on September 28, 2006.

Accepted for publication on Decenber 13, 2006. and, by the age of 4 months, most of them develop cyanosis which is normally progressive, a fact leading to delayed growth and development. In addition, fatigue and breathlessness during exercise and episodes of hypoxia are common in these patients. Beta-adrenergic receptor blockers are of great therapeutic value in the care of patients with functional obstruction of ventricular flow. In this respect, propranolol is used successfully in three situations: management of an acute dyspnea attack, prevention of episodes of dyspnea, and improvement of the clini- 
cal conditions of children who await for surgical correction. On the other hand, there is a disadvantage in clinical practice because propanolol may cause serious respiratory problems, changes in cardiac output and cardiac insufficiency, all related to the high doses of propranolol required to maintain efficacy ${ }^{2}$. Patients with tetralogy of Fallot should be submitted to surgical correction consisting of the closure of the ventricular septal defect with alleviation of right ventricular flow obstruction ${ }^{3,4,5}$. Administration of propranolol during the preoperative period is advantageous and reduces the incidence of ischemic events, hypertension and secondary tachyarrhythmias ${ }^{6}$. Because cardiopulmonary bypass (CPB) and hypothermia cause changes in plasma propranolol concentrations, drug monitoring during and after surgery becomes important.

Different methods have been developed to determine plasma propranolol concentrations, including fluorimetry 7,8,9, gas chromatography ${ }^{10}$, and high-performance liquid chromatography with fluorescence detection (HPLC-F) ${ }^{11-}$ 16. More recently, an analytical method for the quantification of propranolol in plasma of postoperative adult patients was proposed by Pereira et al (2000). Although this method was found to be selective, its sensitivity was relatively low for our purpose. Therefore, once the washout of propranolol was investigated in pediatric patients undergoing surgical correction of tetralogy of Fallot, the objective of the present study was to optimize a new method with high sensitivity to determine lower propranolol plasma concentrations in the perioperative period.

\section{EXPERIMENTAL}

\section{Clinical protocol and blood sample collection}

The study protocol was approved by the Ethics Committees of the Institutions participating of the investigation. Before inclusion in the study, the parents or legal representatives of all children provided a written informed consent to participate of the study. Patients using vasoactive drugs, with episodes of bronchospasm, or without indication for a beta-blocker drug were excluded from the study.

Table 1 summarizes the individual characteristics of six patients with tetralogy of Fallot with surgical indication for the corrective repair of the congenital anomaly. Patients allocated for the study were children of both sexes $(4 \mathrm{M} / 2 \mathrm{~F})$ $11.5+/-3.9 \mathrm{~kg}, 2.1+/-1.3 \mathrm{yrs}, 0.8+/-0.1 \mathrm{~m}$ (height), 18.9+/$6.4 \mathrm{~kg} / \mathrm{m} 2$ (body mass index). They received a long term treatment dose adjusted (1 to $3 \mathrm{mg} / \mathrm{kg}$ of propranolol, three

Table 1. Characteristics of the patients studied and daily dose of propranolol administered in the preoperative period.

\begin{tabular}{lcccccc}
\hline Patient & Gender & Age (years) & Weight $(\mathrm{kg})$ & Height $(\mathrm{m})$ & BMI $(\mathrm{kg} / \mathrm{m} 2)$ & Daily dose $\mathrm{mg} / \mathrm{kg} / \mathrm{day}$ \\
\hline 1 & $\mathrm{M}$ & 0.6 & 9.9 & 0.8 & 17.6 & 9.0 \\
2 & $\mathrm{M}$ & 2.7 & 13.2 & 0.9 & 16.3 & 1.5 \\
3 & $\mathrm{~F}$ & 2.2 & 12.9 & 0.9 & 16.7 & 4.5 \\
4 & $\mathrm{M}$ & 4.0 & 16.5 & 0.7 & 31.8 & 1.8 \\
5 & $\mathrm{M}$ & 2.6 & 11.3 & 0.9 & 15.2 & 5.4 \\
6 & $\mathrm{~F}$ & 0.5 & 11.5 & 0.6 & 15.9 & 3.0 \\
Mean & - & 2.1 & 3.9 & 0.8 & 6.1 & 2.9 \\
SD & - & 1.3 & $8.4-14.6$ & $0.7-0.9$ & $13.8-24.0$ & 2.0 \\
$95 \% \mathrm{CI}$ & - & $1.0-3.2$ & &
\end{tabular}

BMI: body mass index; SD: standard deviation; 95\% CI: upper and lower limits of the 95\% confidence interval.

Table 2. Last dose administered before surgery and interval between the administration of the last preoperative propranolol dose and the beginning of surgery.

\begin{tabular}{|c|c|c|c|c|c|c|}
\hline Allocation & $\begin{array}{c}\text { Last preoperative } \\
\text { dose }(\mathrm{mg})\end{array}$ & $\begin{array}{c}\text { Time between } \\
\text { last dose and } \\
\text { begin of surgery (min) }\end{array}$ & $\begin{array}{l}\text { Duration } \\
\text { of surgery } \\
\text { (min) }\end{array}$ & $\begin{array}{l}\text { Duration } \\
\text { of CPB } \\
\text { (min) }\end{array}$ & $\begin{array}{c}\mathrm{Ht} \% \\
\text { Begin of } \\
\text { surgery }\end{array}$ & $\begin{array}{l}\mathrm{Ht} \% \\
\mathrm{CPB}\end{array}$ \\
\hline 1 & 10 & 600 & 360 & 120 & 43 & 23 \\
\hline 2 & 10 & 720 & 240 & 110 & 38 & 21 \\
\hline 3 & 10 & 636 & 230 & 100 & 40 & 22 \\
\hline 4 & 10 & 720 & 241 & 100 & 46 & 27 \\
\hline 5 & 5 & 1362 & 190 & 116 & 34 & 15 \\
\hline 6 & 5 & 618 & 438 & 138 & 50 & 19 \\
\hline Mean & 8.3 & 776.0 & 283.2 & 114.0 & 41.8 & 21.2 \\
\hline $\mathrm{SD}$ & 2.6 & 291.6 & 94.9 & 14.3 & 5.7 & 4.0 \\
\hline $95 \% \mathrm{CI}$ & $6.3-10.4$ & $542.7-1009.3$ & $207.2-359.1$ & $102.6-125.4$ & $37.2-46.4$ & $17.9-24.4$ \\
\hline
\end{tabular}

CPB: cardiopulmonary bypass; Ht: hematocrit; SD: standard deviation; $95 \%$ CI: upper and lower limits of the $95 \%$ confidence interval. 
times a day) in the ambulatory as follows: $4.2+/-2.8 \mathrm{mg} /$ $\mathrm{kg}$ a day, orally.

The last preoperative dose was administered the night before the day of surgery. The interval between the last dose and the beginning of surgery, the duration of surgery and of the $\mathrm{CPB}$, and the hematocrit value are summarized in Table 2 as individual and population data.

Seven blood samples ( $2 \mathrm{~mL}$ each) were collected at the following times: at the beginning of surgery, at the beginning of $\mathrm{CPB}$, during $\mathrm{CPB}$, at the end of $\mathrm{CPB}$, at the end of surgery, and 24 and $48 \mathrm{~h}$ after surgery. Blood was collected into tubes containing EDTA sodium, centrifuged at 3000 $g$ for $30 \mathrm{~min}$, and plasma was stored at $-20^{\circ} \mathrm{C}$ until assay; total volume of blood collected was lower than $20 \mathrm{~mL}$. The samples were analyzed in parallel to the calibration daily curve and internal controls in three different concentrations (low, medium and high). Data obtained from patients were normalized with hematocrit before surgery using the following equation:

$\mathrm{C}_{\mathrm{n}}=\left(\mathrm{C}_{\mathrm{ob}}\right) \times\left(\mathrm{Ht} \%_{\text {basal }} / \mathrm{Ht} \%_{\text {period }}\right)$

where,

Normalized and obtained data were plasma concentrations of the drug

Ht basal: hematocrit before surgery

Ht period: hematocrit obtained in each period

\section{Analytical procedure}

\section{Liquid-liquid extraction for the clean-up of biological sample}

A simple liquid-liquid extraction was employed for the determination of propranolol plasma levels. For this, $0.2 \mathrm{~mL}$ aliquots of plasma were added to $0.2 \mathrm{~mL}$ internal standard (10 mg/L verapamil hydrochloride, 250ng/assay), $0.2 \mathrm{~mL}$ $1.25 \mathrm{M}$ sodium hydroxide and $3 \mathrm{~mL}$ dichloromethane. Then, the mixture was vortexed for $1 \mathrm{~min}$ and centrifuged at 3000 $g$ for $30 \mathrm{~min}$. The supernatant was aspirated and discarded; the tube containing the organic phase was immersed in a liquid nitrogen bath, and the organic extract was carefully transferred to a conic tube and concentrated to dryness under a nitrogen flow in a water bath at $37^{\circ} \mathrm{C}$. Next, the dry extract was dissolved with $0.2 \mathrm{~mL}$ of a mixture of acetonitrile and water $(8: 2, \mathrm{v} / \mathrm{v})$ and $0.02 \mathrm{~mL}$ volumes were injected automatically into the liquid chromatograph.

\section{Chromatographic analysis}

The samples were analyzed by HPLC-F in a Shimadzu LC-10A liquid chromatograph (Kyoto, Japan) using a Shim-Pack CLC ODS C18 reverse-phase column (Shimadzu; 5 micron, $150 \times 6.0 \mathrm{~mm}$ length $\times$ internal diameter) adapted to an insert NovaPak C18 Waters Assoc. (Milford, USA). The binary mobile phase consisted of $0.1 \mathrm{M}$ acetate buffer, $\mathrm{pH} 5.0$, and acetonitrile $(60: 40, \mathrm{v} / \mathrm{v})$ at a flow rate of $0.7 \mathrm{~mL} / \mathrm{min}$ in an isocratic elution system. The peaks were monitored with an RF 10 AXL fluorescence detector (Shimadzu) at excitation and emission wavelengths of 290 and $358 \mathrm{~nm}$, respectively. The peak areas for propranolol and the internal standard were integrated using a Chromatopac CR-6A integrator Shimadzu (Kyoto, Japan).

\section{Validation of the analytical method}

The calibration curve was obtained using aliquots of a stock solution of the drug $(1 \mathrm{mg} / \mathrm{mL})$ diluted in drugfree human plasma (blank) and stored at $-20^{\circ} \mathrm{C}$. The following concentrations of the standard propranolol solution in plasma were prepared: $1000,500,100,50,25$, $10,5,2.5,1,0.5$, and $0.05 \mathrm{ng} / \mathrm{mL}$. The internal standard, verapamil hydrochloride $(10 \mathrm{mg} / \mathrm{L}$, working solution) was prepared from a stock solution $(1000 \mathrm{mg} / \mathrm{L}$, aqueous) distributed in small aliquots and stored at $-20^{\circ} \mathrm{C}$ until assay.

Each nominal propranolol plasma concentration was plotted against the respective peak area ratio obtained for the drug and its internal standard; in addition the linear correlation coefficient $(\mathrm{r} 2>0.98)$ and its respective equation $(\mathrm{Y}=\mathrm{AX}+\mathrm{B})$ were calculated. At least five of the nine calibration standards were considered for the construction of the daily calibration curve $(0.05-100 \mathrm{ng} /$ $\mathrm{mL}$ ).

The internal controls (80, 40 and $0.5 \mathrm{ng} / \mathrm{mL}$ ) were prepared in duplicate and analyzed during each analytical run to guarantee the acceptance of daily calibration curve. An analytical run was accepted when at least four of the six controls presented a deviation of less than $15 \%$ (for high and medium controls) or less than $20 \%$ (for the low control) from the nominal concentration. Then, the calibration curve was applied to quantify propranolol in plasma samples collected from patients included in the clinical protocol.

The linearity of the method was determined using ten propranolol concentrations in triplicate. The detection and quantification limits were evaluated based on the analysis of 10 replicates. The quantification limit was defined as the lowest plasma concentration of the daily calibration curve quantified with acceptable precision and accuracy. The detection limit was defined as one half of the quantification limit. Absolute recovery was determined using three drug concentrations $(80,40$ and $0.5 \mathrm{ng} / \mathrm{mL}$ ) in five 
replicates and expressed as percentage. The accuracy of the method was evaluated using three concentrations (low, medium and high) in six replicates, and the systematic error of the assay was determined based on the percentage of inaccuracy. Intra-day precision was determined based on the analysis of three concentrations in duplicate, whereas inter-day precision was evaluated by the duplicate analysis of three concentrations $(80,40$ and $0.5 \mathrm{ng} / \mathrm{mL})$ on three consecutive days, for a total of 18 assays.

For the determination of the stability of propranolol in plasma, less than $15 \%$ (highest concentration) and $20 \%$ (lowest concentration) variation was adopted as an acceptable criterion for all concentrations studied. Stability was analyzed after three freezing/thawing cycles of the drug in the biological sample. For the analysis, samples of two propranolol concentrations (250 and $16 \mathrm{ng} / \mathrm{mL}$ ) were analyzed in triplicate on 3 consecutive days, corresponding to freezing/thawing cycles 1,2 and 3 .

The short-, medium- and long-term stability of the drug was also analyzed. Stability was evaluated as a function of time and storage conditions using extracted samples, in at least three concentrations $(16,62.5$ and 250ng/ $\mathrm{mL})$ in replicates $(\mathrm{n}=3) \mathrm{kept}$ at room temperature on the tray of the auto-sampler for the maximum time any sample could remain in this condition. For the determination of short-term stability, two concentrations were submitted to three freezing/thawing cycles in triplicate for each cycle. Long-term stability was determined using two concentrations ( 8 and $500 \mathrm{ng} / \mathrm{mL}$ ) in replicates $(\mathrm{n}=3)$ stored for different periods of time up to 12 months, thus guaranteeing stability during the study period; the results are reported as percentage.

Robustness of the method was determined using two analytical C18 columns of different batches supplied by the same manufacturer, and using small variations in the proportion of the constituents and in the flow rate of the mobile phase. Six replicates were analyzed and the results are reported as a function of the coefficient of variation. The influence of room temperature variations could be ruled out since the temperature in the laboratory was monitored twice daily and was kept at $21 \pm 2^{\circ} \mathrm{C}$.

\section{Statistical analysis and calculation of the mean residence time}

The normalized plasma propranolol concentrations were plotted as a function of sampling time. The mean residence time of the drug was determined using the PK Solutions 2.0, Non Compartment Data Analysis software (Ashland $\mathrm{OH}, \mathrm{USA})$.

The GraphPad Instat software 3.0 (GraphPad Instat Inc., San Diego CA, USA) was used for statistical analysis, and paired data were compared by ANOVA and Wilcoxon or Friedman tests. The results are reported as median, 95\% confidence interval $(95 \% \mathrm{CI})$ for drug concentration. The characteristics of patients were expressed as mean $+/$-standard deviation of the mean.

\section{RESULTS}

\section{Validation of the analytical method}

The specificity of the analytical method for the quantification of propranolol in biological samples was evaluated by injecting extracts of normal $(n=2)$, lipemic $(n=2)$ and hemolysate $(n=2)$ plasma into the chromatographic system. The endogenous components eluted from the chromatographic column did not interfere with the analysis under the conditions described above, with the chromatogram peaks obtained for the endogenous components differing from the retention times obtained for propranolol and the internal standard (verapamil), as can be seen in Figure 1.
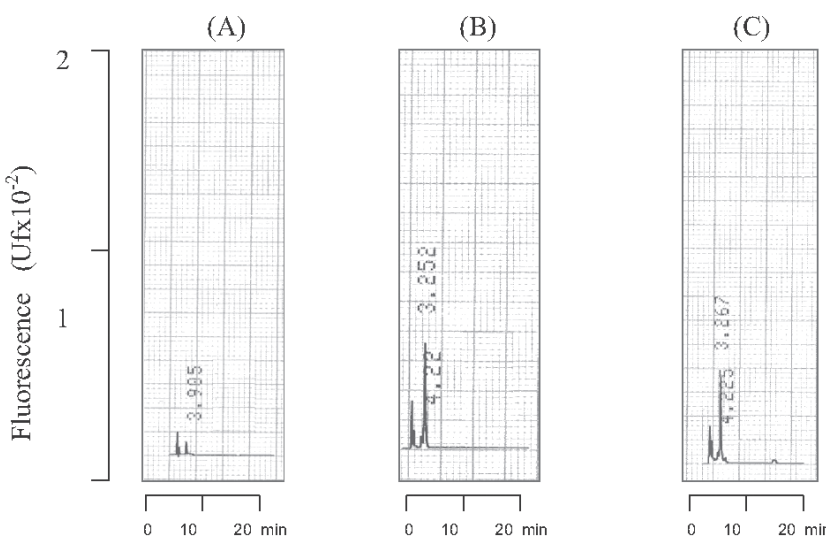

Figure 1: Chromatographic profiles of plasma propranolol and its internal standard (verapamil). Chromatograms: (A)Normal plasma (B) Lipemic plasma (C) Hemolysate plasma.

The peaks corresponding to propranolol and internal standard were eluted from the chromatographic column at 8.4 and $17.5 \mathrm{~min}$, respectively. The chromatographic profile of the determination of propranolol in plasma is shown in Figure 2, which illustrates the analysis of a plasma blank, blank of plasma sample spiked (propranolol $5 \mathrm{ng} / \mathrm{mL}$, plasma standard) with addition of the internal standard and plasma of a patient receiving propranolol. Detection by fluorescence (290 nm and $358 \mathrm{~nm}$ for excitation and emission wavelengths, respectively) showed high sensitivity and good selectivity. The total time required for each chromatographic run was $20 \mathrm{~min}$.

The daily calibration curve (Figure 3 ) showed excellent linearity ( $\mathrm{r} 2$ : 0.9998), and only $0.2 \mathrm{~mL}$ of the biological sample was required. Thus, the new analytical HPLC-F method proposed was selective and sensitive for the quan- 
(A)

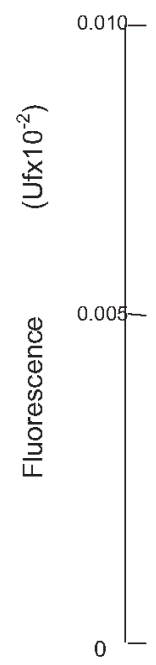

(B)

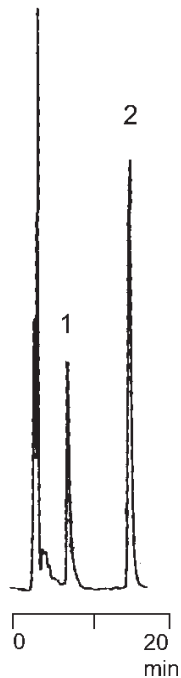

(C)

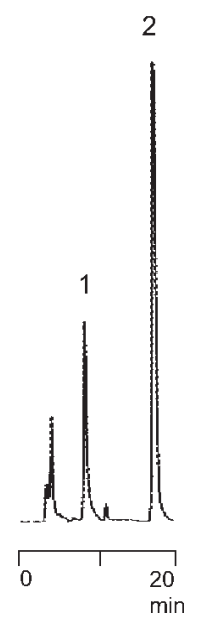

Figure 2: Chromatographic profile of plasma propranolol and its internal standard (verapamil). Chromatograms: (A) Blank of plasma samples without internal standard (IS), (B) blank of plasma sample spiked (propranolol 5ng/ $\mathrm{mL}$ ) plus IS. (C) plasma of a patient receiving propranolol. Retention times: 1) Propranolol $8.4 \mathrm{~min}$ and, 2) Verapamil (IS) $17.5 \mathrm{~min}$.

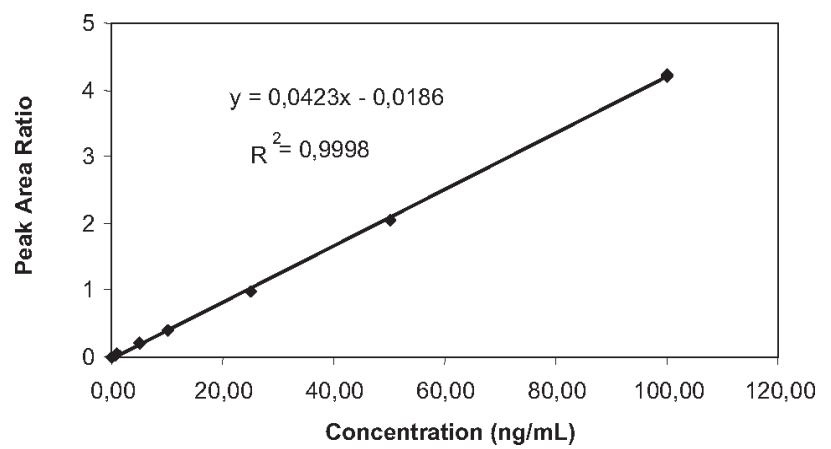

Figure 3. Calibration daily curve of propranolol in plasma, blank plasma spiked to obtain six concentrations of propranolol.

tification of propranolol in plasma using a C18 column, a binary mobile phase and low flow rate.

The method developed presented high sensitivity (quantification limit $=0.05 \mathrm{ng} / \mathrm{mL}$ and detection limit $=0.02$ $\mathrm{ng} / \mathrm{mL}$ ), linearity in the range of 0.05 to $1000 \mathrm{ng} / \mathrm{mL}$ with a linear coefficient of 0.9998 , good recovery $(97 \%)$, and acceptable precision (intra-day $4.7 \%$ and inter-day $=8.6 \%$ ) and accuracy $(3.1 \%)$. In addition data from studies of stability and robustness were included (Table 3 - 4).

Robustness of the method was analyzed based on analysis using different $\mathrm{C} 18$ columns (1.5\%), variations in the composition or final $\mathrm{pH}$ of the mobile phase $(6.4 \%)$, or in the flow rate $(2,4 \%)$, as a function of the coefficient of variation.

Analysis of the stability on freezing/thawing cycle showed that propranolol concentration remained stable for at least three cycles for the two concentrations analyzed in triplicate (16 and $250 \mathrm{ng} / \mathrm{mL}$ ), with a good coefficient

Table 3. Confidence limits of the analytical method for the determination of propranolol in plasma.

\begin{tabular}{|c|c|c|}
\hline Parameters & Unit & Propranolol \\
\hline Linearity & $\mathrm{ng} / \mathrm{mL}$ & $0.05-100$ \\
\hline Linear correlation coefficient $\left(\mathrm{r}^{2}\right)$ & & $\mathrm{r}^{2}: 0.9998$ \\
\hline Detection limit & $\mathrm{ng} / \mathrm{mL}$ & 0.02 \\
\hline Quantification limit & $\mathrm{ng} / \mathrm{mL}$ & 0.05 \\
\hline Absolute recovery $(80,40$ e $0.5 \mathrm{ng} / \mathrm{mL})$ & $(\%)$ & 95.0 \\
\hline Precision $(80,40$ e $0.5 \mathrm{ng} / \mathrm{mL})$ & & \\
\hline -Inter-day (mean, SD) & $(\%)$ & $8.6+/-3.9$ \\
\hline -Intra-day & $(\%)$ & $4.7+/-4.3$ \\
\hline $\begin{array}{l}\text { Systematic error (inaccuracy) } \\
(80,40 \text { e } 0.5 \mathrm{ng} / \mathrm{mL})\end{array}$ & $(\%)$ & $3.1+/-2.9$ \\
\hline Robustness (mean) & & \\
\hline . C18 columns ( 2 batches). & $(\mathrm{CV} \%)$ & 1.5 \\
\hline Flow rate $(+/-0.1 \mathrm{~mL})$ & $(\mathrm{CV} \%)$ & 2.4 \\
\hline $\begin{array}{l}- \text { Mobile phase } \\
(+/-1 \% \text { in the proportion of acetonitrile) }\end{array}$ & $(\mathrm{CV} \%)$ & 6.4 \\
\hline
\end{tabular}

SD: standard deviation; $\mathrm{CV}$ : coefficient of variation.

of variation, as seen in Table 4.

The maximum time the sample remains on the tray of the automatic injector before analysis showed that propranolol remained stable for a least $18 \mathrm{~h}$. The procedure was conducted for different concentrations $(16,62.5$ and $250 \mathrm{ng} / \mathrm{mL}$, replicates $\mathrm{n}=3$ ) and a coefficient of variation equivalent to $3.8 \%$ was obtained, as shown in Table 4.

Regarding long-term stability, propranolol standards in the biological sample were found to be stable in a freezer $\left(-20^{\circ} \mathrm{C}\right)$ for a minimum period of 24 months; a coefficient of variation of $0.8 \%$ was obtained for the assay performed in triplicate for propranolol high and low concentrations (500 and 8 $\mathrm{ng} / \mathrm{mL}$, respectively) in blank plasma spiked (Table 4).

Table 4. Stability studies of propranolol in biological matrices

\begin{tabular}{lcc}
\hline & Concentration & Variation \\
\hline Stability after three freeze-thaw cycles & $16 \mathrm{ng} / \mathrm{mL}$ & $8.6 \%$ \\
& $250 \mathrm{ng} / \mathrm{mL}$ & $7.3 \%$ \\
Short-term stability & $16 \mathrm{ng} / \mathrm{mL}$ & $1.5 \%$ \\
& $62.5 \mathrm{ng} / \mathrm{mL}$ & $2.4 \%$ \\
& $250 \mathrm{ng} / \mathrm{mmL}$ & $7.5 \%$ \\
Long-term stability & $8 \mathrm{ng} / \mathrm{mL}$ & $1.3 \%$ \\
& $500 \mathrm{ng} / \mathrm{mL}$ & $0.5 \%$ \\
\hline
\end{tabular}

\section{Therapeutic drug monitoring}

The validated analytical method was applied for drug monitoring of plasma concentrations in six patients undergoing heart surgery for the correction of a congenital anomaly (tetralogy of Fallot). Analyses were performed using a daily calibration standard curve accepted by the internal controls and propranolol plasma concentrations in patient samples were estimated by the linear regression equation. 
The mean duration of surgery was $5.03 \mathrm{~h}(301.7 \pm 99.6$ min), with the patient remaining under CPB for $1.94 \mathrm{~h}$ $(116.3 \pm 14.4 \mathrm{~min})$. Surgery was started $12.74 \mathrm{~h}(794.9 \pm$ $270.8 \mathrm{~min}$ ) after administration of the last dose of propranolol $(8.7 \pm 2.7 \mathrm{mg})$, as shown inTable 2 .

The declining curve of propranolol plasma concentration obtained from patients after the last dose in the night that preceded the day of surgery is illustrated in Figure 4.

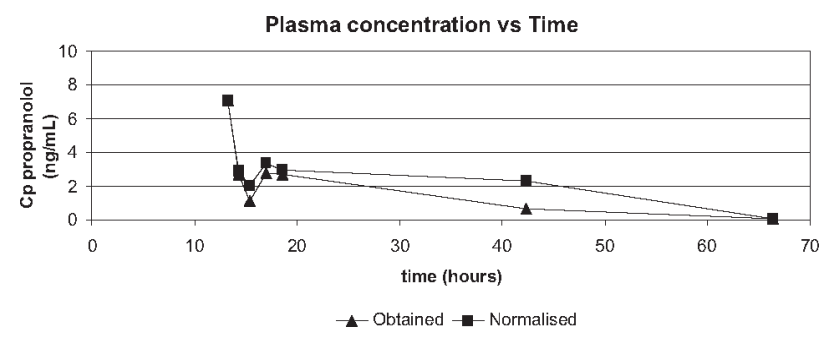

Figure 4 - Propranolol plasma levels (medians, n:6), during the surgery with hypothermic cardiopulmonary bypass, after the last administered dose in the preoperative of $8,86 \mathrm{mg}$, normalized relative to the hematocrit.

The effect of hemodilution that occurs during the surgical intervention on propranolol plasma concentrations (data obtained and data normalized with hematocrit) was investigated by comparison. It showed no significant difference at the beginning of surgery $(7.09$ and $7.09 \mathrm{ng} / \mathrm{mL}$, $\mathrm{p}=1.0000$ ) as well as at the end of surgery (2.70 and 2.94 $\mathrm{ng} / \mathrm{mL}, \mathrm{p}=0.1250$ ), Table 5. However, significant differences were observed by comparison of drug concentrations (obtained versus normalized) during CPB (1.14 versus 2.06 $\mathrm{ng} / \mathrm{mL}, \mathrm{p}=0.0313)$ and after the CPB (2.79 versus $3.37 \mathrm{ng} /$ $\mathrm{mL}, \mathrm{p}=0.0313$ ), as seen in Table 5 .

On the other hand, by comparison between periods, normalized data showed a significant decrease on drug concentrations $(\mathrm{p}<0,05)$ from the beginning of surgery $(7.09$ $\mathrm{ng} / \mathrm{mL})$ to the postoperative day $2(0.05 \mathrm{ng} / \mathrm{mL})$ and also, a significant reduction from the end of CPB $(2.79 \mathrm{ng} / \mathrm{mL})$ to the postoperative day $2(0.05 \mathrm{ng} / \mathrm{mL}, \mathrm{p}<0.05)$.

Finally, by applying a noncompartmental analysis PK solutions 2.0 software, the mean residence time estimated for propranolol during the period of study was $35.8 \mathrm{~h}$.

\section{DISCUSSION}

\section{Validation of the analytical method}

Before the quantification of drug by HPLC-F, with respect to the clean-up of the biological sample, Heeden (1991) described a selective but expensive procedure consisting of solid extraction of propranolol from plasma using Bond Elut columns using two extraction steps. The minimum detectable concentration was $1.0 \mathrm{ng}$ in $1 \mathrm{~mL}$ plasma. In the present study, simple liquid-liquid extraction with dichloromethane, proposed to quantify propranolol plasma concentrations, presents an absolute recovery comparable to those reported previously with a relative low cost method ${ }^{11,13,18}$. A detection limit of $20 \mathrm{ng} / \mathrm{mL}$ using $0.4 \mathrm{~mL}$ plasma was described by Lo and Riegelman (1980), whereas Drummer et al (1981), Harrison et al (1985) and Pereira et al (2000) reported for assays employing higher volumes of plasma, detection limits of 2, 1 and $0.5 \mathrm{ng} / \mathrm{mL}$, respectively. In the present method, $0.02 \mathrm{ng} / \mathrm{mL}$ was determined by our procedure, once the detection limit was increased by 20 times compared to Pereira et al, 2000 .

As regards chromatographic systems previously described, ion-pair liquid chromatography requires modifying reagents added to the mobile phase, such as alkylamines (triethylamine) and sulfonic acids, in addition to a high flow rate for elution of the analyte. On the other hand, reversephase liquid chromatography using an isocratic elution system has been preferred over those previously described. Consequently, in the present study the binary system using reverse-phase chromatography was found to be the best alternative among the most complex systems reported in the literature ${ }^{14-16,19}$. Despite the good selectivity obtained with complex systems, an evident limitation of the reported methods is the high flow rate $(1.5-2.0 \mathrm{~mL} / \mathrm{min})$ required to elute the drug $11-13,20,21$.

Table 5. Comparison of propranolol plasma concentrations during the surgery in patients with tetralogy of Fallot, medians, $\mathrm{n}=6$.

\begin{tabular}{lccc}
\hline Period & data obtained $\mathrm{ng} / \mathrm{mL}(\mathrm{IC} 95 \%)$ & normalised data $\mathrm{ng} / \mathrm{mL}(\mathrm{IC} 95 \%)$ & ${\text { Probability }(\mathrm{p}) \text { Wilcoxon } \text { test }^{\mathrm{a}}}$ \\
\hline Beginning of surgery & $7.09(1.76-15.80)$ & $7.09(1.76-15.80)$ & $\mathrm{p}=1.0000$ \\
End of surgery & $2.70(1.22-4.68)$ & $2.94(1.27-5.66)$ & $\mathrm{p}=0.1250$ \\
Beginning of CPB & $2.69(0.44-8.56)$ & $2.87(0.58-8.60)$ & $\mathrm{p}=0.5000$ \\
Intra - CPB & $1.14(0.24-4.29)$ & $2.06(0.49-8.91)$ & $\mathrm{p}=0.0313$ \\
End of CPB & $2.79(1.45-8.52)$ & $3.37(1.31-11.57)$ & $\mathrm{p}=0.0313$ \\
PO 1 $1^{\text {st }}$ day & $0.63(0.00-3.88)$ & $2.28(0.51-4.21)$ & $\mathrm{p}=0.4375$ \\
PO 2 ${ }^{\text {nd }}$ day & $0.05(0.00-2.31)$ & $0.05(0.00-1.92)$ & $\mathrm{p}=0.9999$ \\
\hline
\end{tabular}

CPB: cardiopulmonary bypass; PO: postoperative period. ${ }^{a}$ Nonparametric statistical analysis for paired data; $\mathrm{p}<0.05$, significance level; data obtained versus data normalised with hematocrit. 
Some modifications introduced in the present method provided a marked increase in the sensitivity, thus requiring validation of the new procedure compared to the procedure described by Pereira and co-workers (2000) once a highly sensitive procedure able to determine picogram amounts of the drug in the plasma is necessary to investigate the washout of propranolol. The main adaptations responsible for the 20 -fold increase in the sensitivity of the method were the use of a mobile phase consisting of a different proportion of acetate buffer, $\mathrm{pH}$ 5.0 , and acetonitrile $(60: 40, \mathrm{v} / \mathrm{v}$, instead of $65: 35)$, a reduction in the ionic strength of the medium using 0.1 $\mathrm{M}$ instead of $0.4 \mathrm{M}$ acetate buffer, $\mathrm{pH} 5.0$, as proposed by Pereira et al (2000) and, finally, replacement of the analytical Nova Pak C18 column (150 x 3.9 mm, $4 \mu \mathrm{m}$; Waters, Milford, USA) with a column of higher capacity and selectivity (Shimpack ODS, $150 \times 6 \mathrm{~mm}, 5 \mathrm{mi}-$ cron; Shimadzu), this modification leading to a marked increase in sensitivity with an additional gain of selectivity and capacity. The method validated was superior to previously reported procedures, because $0.05 \mathrm{ng} / \mathrm{mL}$ could be quantified by HPLC-F in $0.2 \mathrm{~mL}$ of plasma. Thus, the binary reverse-phase chromatography system described in the present study seems to be the best choice in view of its selectivity, marked sensitivity, and operation at low flow.

Analysis of the robustness of the method demonstrated its reproducibility. In addition, propranolol was found to be stable under the conditions analyzed, considering its short-term stability (freezing/thawing cycle), stability over time and under the storage condition used, and long-term stability. It should be emphasized that no stability or robustness studies were performed earlier.

\section{Quantification of propranolol in plasma of patients submitted to surgical correction of tetralogy of Fallot}

In outpatients with tetralogy of Fallot chronically treated with propranolol, the effective plasma levels of the drug should range from 40 to $90 \mathrm{ng} / \mathrm{mL}^{22}$. A reduction in the propranolol dose before heart surgery is necessary to prevent complications during the intervention including a low cardiac output in the postoperative period. On the other hand, administration of propranolol before surgery prevents episodes of hypoxemia during the induction of anesthesia. However, the recommended period for discontinuation of the drug prior to the surgery is still controversial. Barazzone and co-workers (1988) proposed an interval of 6 to $8 \mathrm{~h}$ after the last propranolol dose, whereas other investigators recommend a longer period ranging from 12-18 $\mathrm{h}$ up to $24 \mathrm{~h}$ (maximum) before the begin- ning of the surgical procedure ${ }^{6,17}$

For interpretation of the results (Table 5), plasma propranolol concentrations were normalized to measure the effect of hemodilution caused by the CPB during the surgery. As can be seen, the obtained and normalized data declined differently during $\mathrm{CPB}, \mathrm{p}<0.05$. Due to re-heating of the patients at the end of CPB, obtained and normalized plasma propranolol concentrations again increased differently, $\mathrm{p}<0.05$. According to Barazzone et al (1988), this increase is mainly due to redistribution of the drug from the lungs to the plasma, a reduction in hepatic metabolism, and a decrease in the volume of distribution as a result of hypothermia. In addition, a reduction in plasma proteins increases the free fraction of the drug by 6.6 to $13.5 \%$, because $90 \%$ of propranolol is bound to plasma protein, especially alpha 1-acid glycoprotein. On the other hand, when CPB is installed and hemodilution occurs, the plasma propranolol concentration decreases by $50 \%$. In addition, fatsoluble drugs such as propranolol are easily sequestered by the circulator, a fact that contributes to a reduction of plasma propranolol levels during $\mathrm{CPB}{ }^{6}$.

In the present study, surgery was started about $15 \mathrm{~h}$ after administration of the last preoperative propranolol dose. Barazzone and co-workers (1988), investigating patients with tetralogy of Fallot who received propranolol, PO, every $8 \mathrm{~h}$ before surgery, reported a median plasma concentration of $18.7 \mathrm{ng} / \mathrm{mL}$ (95\% CI, 3.4-61.5) at the beginning of $\mathrm{CPB}$, whereas in the present study a median plasma concentration of $2.87 \mathrm{ng} / \mathrm{mL}(0.49-8.91)$ was observed. This difference might be explained by the different time intervals between the last preoperative dose administered and the beginning of CPB, which was approximately $15 \mathrm{~h}$ in the present study versus $8 \mathrm{~h}$ in the investigation of Barazzone et al (1988). In addition, plasma propranolol concentration was $2.28 \mathrm{ng} / \mathrm{mL}(0.51-4.21) 24$ $\mathrm{h}$ after the beginning of surgery, i.e., during the late postoperative period, compared to $1.0-5.6 \mathrm{ng} / \mathrm{mL}$ reported by Barazzone et al (1988). In fact, concentrations found were lower than the recommended to maintain efficacy (40-90 $\mathrm{ng} / \mathrm{mL}$ ); our data suggests that the washout of propranolol was completed by the second postoperative day as demonstrated by the mean residence time of drug.

\section{CONCLUSION}

The validated analytical method showed good linearity, sensitivity, accuracy and precision for the determination of propranolol in plasma at low concentrations. Robustness and stability studies were acceptable.

The effect of hemodilution on propranolol plasma concentrations during CPB procedure was verified. Drug moni- 
toring after the last preoperative dose revealed a decline of plasma concentrations, data normalized, from the beginning of surgery up to the second postoperative day, suggesting that, once redistribution was restored at the end of surgery, propranolol washout was complete.

\section{ACKNOWLEDGMENTS}

To Brazilian Foundation for Research CAPES, CNPq and FAPESP for financial support.
Sanches C, Galas FRBG, Silva AGO de M, Carmona MJC, Auler Jr. JO, Santos S R CJ. Monitoramento do propranolol plasmático em crianças operadas da tetralogia de Fallot através de micrométodo utilizando a cromatografia líquida de alta eficiência. Clinics. 2007;62(3):215-24.

OBJETIVO: Avaliar o micrométodo analítico empregando a cromatografia líquida para quantificação de propranolol em crianças operadas de tetralogia de Fallot (TLF).

MÉTODO: Requereu-se apenas volumes de $0,2 \mathrm{~mL}$ de plasma para a realização do ensaio. Os picos foram eluídos em 8.4 (Propranolol) e 17.5 min (verapamil, padrão interno) de uma coluna $\mathrm{C} 18$, com fase móvel (tampão acetato 0,1 $\mathrm{M} \mathrm{pH} \mathrm{5,0} \mathrm{e} \mathrm{acetonitrila,} \mathrm{60:40,} \mathrm{v/v)} \mathrm{em} \mathrm{fluxo} \mathrm{de} 0,7 \mathrm{~mL} /$ 
min, sendo detectados em 290 nm (excitação) e em 358 $\mathrm{nm}$ (emissão). A cirurgia iniciou-se 776 min depois da dose administrada $(8,7 \mathrm{mg}$, média) e sete amostras de sangue foram coletadas de seis pacientes $(4 \mathrm{M} / 2 \mathrm{~F} ; 2,1$ anos; $11,5 \mathrm{~kg}$; $\left.0,80 \mathrm{~m} ; 18,9 \mathrm{~kg} / \mathrm{m}^{2}\right)$.

RESULTADOS: Os limites de confiança do método analítico evidenciaram alta seletividade e recuperação, sensibilidade $(0,02 \mathrm{ng} / \mathrm{mL})$, boa linearidade $(0,05-1000 \mathrm{ng} /$ $\mathrm{mL}$ ), precisão de $8,6 \%$ e exatidão de $3,1 \%$. A duração média da cirurgia foi de 283,2min, com os pacientes em circulação extracorpórea (CEC) durante 114min. Uma curva de declínio do propranolol no plasma foi obtida após a última dose na noite que precedeu o dia da intervenção. A concentração plasmática foi normalizada com o hematócrito devido à hemodiluição causada pela
CEC. Por outro lado obteve-se decréscimo nas concentrações plasmáticas entre os períodos início da cirurgia para o $2^{\circ}$ dia de pós-operatório $(7,09 \mathrm{ng} / \mathrm{mL}$ e0,05 $\mathrm{ng} / \mathrm{mL}, \mathrm{p}<0,05$ respectivamente) e do final da CEC para o $2^{\circ}$ dia de pós-operatório $(2,79 \mathrm{ng} / \mathrm{mL}$ e $0,05 \mathrm{ng} / \mathrm{mL}$, $\mathrm{p}<0,05)$.

CONCLUSÃO: O monitoramento das concentrações plasmáticas normalizadas do propranolol, em crianças com TLF, após a última dose pré-operatória revelou decaimento do início da cirurgia para o segundo pós-operatório, sugerindo que após a correção cirúrgica, uma vez restaurada a distribuição, a eliminação do fármaco foi completa.

UNITERMOS: Propranolol, Micrométodo, Concentrações plasmáticas, Tetralogia de Fallot.

\section{REFERENCES}

1. Hay Jr WW, Groothuis JR, Hayward AR, Levin MJ. Cyanotic Heart Disease. In: Current Pediatric Diagnosis and Treatment, 11th ed., London: Prentice Hall International; 1993;550-552.

2. Cumming GR. Propranolol in Tetralogy of Fallot. Circulation. 1970;41(1):13-15.

3. Van Arsdell GS, Maharaj GS, Tom J, Rao VK, Coles JG, Freedom RM, et al. What is the Optimal Age for Repair of Tetralogy of Fallot. Circulation. 2000;102 (19 suppl 3):III123-9

4. Pigula FA, Khalil PN, Mayer JE, Del Nido PJ, Jonas RA. Repair of Tetralogy of Fallot in Neonates and Young Infants. Circulation. 1999;100(19 supp 1):III157-61.

5. Garson A, Gorry GA, Mcnamara DG, Cooley DA. The Surgical Decision in Tetralogy of Fallot: Weighing Risks and Benefits with Decision Analysis. Am. J. Cardiol. 1980;45(1):108-116.

6. Carmona MJC, Malbouisson LMS, Pereira VA, Bertoline MA, Omosako CEK, Le Bihan KB, et al. Cardiopulmonary bypass alters the pharmacokinetics of propranolol in patients undergoing cardiac surgery. Brazilian Journal of Medical and Biological Research. 2005; 38(5):713721
7. Boudoulas H, Snyder GL, Lewis RP, Kate RE, Karayanncos PE, Vasko JS. Safety and rational for continuation of propranolol therapy during coronary bypass operation. Ann Thorac. Surg. 1978;26(3):222-7.

8. Rao OS, Quesada LC, Mueller HS. A simple micromethod for simultaneous determination of plasma propranolol and 4hydroxipropranolol. Clin Chim Acta. 1978;88(2):355-61.

9. Shand DG, Nuckolls EM, Oates JA. Plasma propranolol levels in adults with observations in four children. Clin. Pharmacol. Ther. 1970;11(1):112-120.

10. Walle T, Morrison J, Walle K, Conradi E. Simultaneous determination of propranolol and 4-hydroxypropranolol in plasma by mass fragmentography. J. Chromatogr. 1975; 114(2):351-359.

11. Drummer OH, Mcneil J, Pritchard E, Louis WJ. Combined highperformance liquid chromatographic procedure for measuring 4hydroxypropranolol and propranolol in plasma: pharmacokinetic measurements following conventional and slow-realease propranolol administration. J. Pharm. Sci. 1981;70(9):1030-1032.

12. Fu CJ, Mason WD. Determination of propranolol and 4hydroxypropranolol in human plasma by high-performance liquid chromatography. Analyst. 1989;114(10):1219-1223. 
13. Harrison PM, Tonkin AM, Cahill CM, Mclean AJ. Rapid and simultaneous extraction of propranolol, its neutral and basic metabolites from plasma and assay by high-performance liquid chromatography. J. Chromatogr. 1985;343(2):349-358.

14. Hedeen KM, Tyczkowska K, Aucoin DP, Norton RM. Rapid highperformance liquid chromatographic method for the determination of propranolol levels in canine and feline plasma. J. Chromatogr. 1991;572(1-2):239-245.

15. Koshakji RP, Wood AJJ. A modified, sensitive liquid chromatographic method for measurement of propranolol with fluorescence detection. J. Pharm. Sci. 1986;75(1):87-89.

16. Sood SP, Green VI, Mason RP. Routine methods in toxicology and therapeutic drug monitoring by high-performance liquid chromatography. IV. A rapid microscale method for determination of propranolol and 4-hydroxypropranolol in plasma. Ther. Drug Monit. 1988;10(2):224-230.

17. Pereira VA, Bertoline MA, Carmona MJC, Auler Jr JOC, Santos SRCJ. High Performance Liquid Chromatography to determine Propranolol in Plasma. Brazilian Journal of Pharmaceutical Sciences. 2000;36(2):241-247.
18. Lo M, Riegelman S. Determination of propranolol and its major metabolites in plasma and urine by high-performance liquid chromatography without solvent extraction. J. Chromatogr. 1980; 183(2):213-220.

19. Modamio P, Lastra CF, Montejo O, Mariño EL. Development and validation of liquid chromatography methods for the quantitation of propranolol, metoprolol, atenolol and bisoprolol: application in solution stability studies. International journal of pharmaceutics. 1996;130:137140

20. Abdel-Hamid ME. Comparative LC-MS and HPLC analyses of selected antiepileptics and beta-blocking drugs. Il Farmaco. 2000;55(2):136145

21. Basci NE, Temizer A, Bozkurt A, Isimer, A. Optimization of mobile phase in the separation of beta-blockers by HPLC. Journal of Pharmaceutical and Biomedical Analysis. 1998;18(4-5):745-750.

22. Ponce FE, Williams LC, Webb HM, Riopel DA, Hahn AR. Propranolol palliation of tetralogy of Fallot: experience with long-term drug treatment in pediatric patients. Pediatrics. 1973; 52(1):100-108.

23. Barazzone C, Jaccard C, Berner M, Dayer P, Rouge JC, Oberhansli I, et al. Propranolol treatment in children with tetralogy of Fallot alters the response to isoprenaline after surgical repair. Br. Heart J. 1988;60(2):156-61 